$\begin{array}{ll}\text { Abstracta Iranica } & \begin{array}{l}\text { Abstracta Iranica } \\ \text { Revue bibliographique pour le domaine irano-aryen }\end{array} \\ & \text { Volume } 26 \mid \mathbf{2 0 0 5} \\ & \text { Comptes rendus des publications de } \mathbf{2 0 0 3}\end{array}$

\title{
« The Stein Khotanese collection ». BAI 13 (1999 [2002]), pp. 204-206.
}

\section{Mauro Maggi}

\section{(2) OpenEdition}

1 Journals

Édition électronique

URL : http://journals.openedition.org/abstractairanica/3581

DOI : 10.4000/abstractairanica.3581

ISSN : 1961-960X

Éditeur :

CNRS (UMR 7528 Mondes iraniens et indiens), Éditions de l'IFRI

\section{Édition imprimée}

Date de publication : 15 mai 2005

ISSN : 0240-8910

\section{Référence électronique}

Mauro Maggi, « « The Stein Khotanese collection ». BAl 13 (1999 [2002]), pp. 204-206. », Abstracta Iranica [En ligne], Volume 26 | 2005, document 29, mis en ligne le 08 décembre 2005, consulté le 25 septembre 2020. URL : http://journals.openedition.org/abstractairanica/3581 ; DOI : https://doi.org/ 10.4000/abstractairanica.3581

Ce document a été généré automatiquement le 25 septembre 2020.

Tous droits réservés 


\section{«The Stein Khotanese collection ». BAI 13 (1999 [2002]), pp. 204-206.}

\section{Mauro Maggi}

1 This short note, which accompanies C. Altman Bromberg's review of H. Wang, ed., Handbook to the Stein collections in the UK (London, The British Museum, 1998), is an abridged version of the first paragraphs devoted to the Stein Khotanese manuscripts of the British Library in Skjærvø's introduction to his Catalogue, pp. xlvii-1 (see c.r. $n^{\circ}$ 28).

\section{INDEX}

Mots-clés : manuscrit, manuscrits khotanèses Thèmes : 2.1. Langues anciennes

Keywords : manuscripts, Khotanese manuscripts

\section{AUTEURS}

\section{MAURO MAGGI}

Istituto Universitario Orientale - Naples 